\title{
THE IDENTITY OF JAVANESE WOMEN (The study of Phenomenology Toward Indonesian Migrant Women Workers)
}

\author{
Anam Miftakhul Huda \\ Universitas Islam Balitar, Email : a6.asix6@yahoo.co.id
}

\begin{abstract}
The woman stands for Java language (wani ditoto) term used for Homo sapiens gender and has reproduction. The opposite sex from the woman is a man or a male. The woman is a word commonly used to describe mature women. Awareness of Indonesian women to work very large, although the country must work out to become migrant workers, this is shown by the increasing number of women migrant workers every year.

Based BNP2TKI report in 2013 the number of migrants reached 512168 people, consisting of 285197 person formal workers (56\%) and 226871 informal migrant workers (44\%). Whereas in 2012 migrant workers reached 494609 people consisting of 258411 formal sector (52\%) and 236198 informal migrant workers $(48 \%)$. (detik.com).

This research using phenomenology approach by deep interview (unstructured) observation non participants and study documentation. The subject in this research is Javanese Indonesian women. The informants of this research are six women workers.

The purpose of this research is expected to describe the shift in the concept of Javanese women carry out tasks in abroad, there are Indonesian cultural values implied by the instincts of a typical traditional Javanese woman, though the housemaids are located in other countries.

Social identity theory is a theory that was originally engaged in the area of Social Psychology, with the language and its ability to find and understand the meaning, has become a meta - theory that is able to bring together many disciplines such as psychology, anthropology, sociology, history, communications, as implications is that reality is always social, and the social contextual character always in a state of local culture and history.

The meaning of something can be very different in cultures or groups of people who are different because in each cultural or community groups have own ways to interpret things. Groups of people who have a background of understanding is not the same to certain cultural codes will not be able to understand the meaning produced by other community groups.

Research described that diversity nations woman patriarchy, Javanese culture properties characteristic of java women clearly reflected in life with workers Indonesia (TKW) is different from another country.
\end{abstract}

\section{Keywords: Women, house maids, Pattern Communication, Cultural Identity Java, house maids Identity.}




\section{BACKGROUND}

Social phenomenon that is currently happening in the community income TKI / TKW abroad very interesting than become servants in their own country. This is no longer a new phenomenon in Indonesia; this is driven by the difficulty of finding Indonesian economy in the absence of skills and higher education. Since the nineteenth century workforce has spread to Suriname, New Caledonia, Siam and Sarawak, there are ten of thousands who work as contract laborers.

Based BNP2TKI report in 2013 the number of migrants reached 512168 people, consisting of 285197 person formal workers (56\%) and 226871 informal migrant workers (44\%). While in 2012 reached 494609 people, which consists of 258411 formal sector $(52 \%)$ and $236 \quad 198$ informal migrant workers (48\%).(detik.com )

The number of workers continues to increase along with the population growth rate is increasing every year, but this is not followed by adequate employment. The low of employment in country and lack of skills, especially for women encourage them to seek and exploit to work abroad.

The women who take advantage of employment opportunities abroad is referred to as the Labor Women (TKW). Each house maid has a reason or background factors driving their decision to work abroad are different between individuals from one another. Those limitation in the family economy that has not been fulfilled and employment opportunities for women are still underappreciated.

Along with the changing times, the role of women in society began to shift. The concept of Java over the domestic woman masak (cook), macak(preen) and manak (give birth) determination and courage to seek life abroad away from their husbands, children their families.

In addition to the women who are married, there is also a desperate young women who decide to work abroad because of the crush of the economy and are tempted to go because their neighbors who had been migrant workers return to their homeland and to live better. 
From this background that this study provides an overview of Javanese women who become migrant workers who have shifts of social reality TKW from which the concept of Java Javanese woman " Masak, Macak, Manak"

\section{RESEARCH METHODOLOGY}

This research is a qualitative description. This means that this study seeks to describe the knowledge and experience of women on perceptions of cultural values as well as the description of the lives of Javanese women migrant workers. This study took place dikabupaten Blitar, The reason for the selection of study sites was based on the consideration that the region is a thick Javanese society values corresponding Javanese culture and the number of migrant workers coming from Blitar.

Informants retrieval techniques used in this study is purposive, ie informants retrieval techniques adapted to the purpose of research. The number of informants is not required, just take informants in accordance with the purposes of research or informants unit adapted to certain criteria set by the research objectives. In this case the samples taken amounted to 6 people who are identified as follows : 1 ) Women who become migrant workers Blitar 2 ) Women who are married and working abroad working.

Information about the issue being studied through the secondary, ie data obtained through other sources outside of informants that have been processed as library research, data from the Central Bureau of Statistics, and the monograph village.

Data collection techniques used were in-depth interviews (In-Depth Interviewing). That conversation with a purpose. Intention of conducting interviews (Lincoln \& Guba, 1985) is contributed, the people, events, activities, organizations, feelings, motivations, demands, concerns and others roundnes. (Moleong, 1998: 135 ).

Interview techniques used in the 'in depth interview 'is a technique which is conducted in-depth interviews, intimate, and open, so that the data can reveal clearly, what it is, is not structured and able to scrape honesty informant. 
In-depth interviews conducted with strict structure, and are "open ended" and done informally informant to express an opinion about a particular event. Interviews can be conducted at a time and context in which it deems appropriate in order to obtain the data which has depths, and can be done repeatedly for the sake of explanation of the problems studied HB Sutopo, 1988: 24).

The method used in the data analysis is interactive model that consists of data reduction, the data display, and conclusion drawing. The third component of the data analysis activities in the form of interaction with the inter-related nature of the cycle and either before, during, and after implementation of data collection.

\section{RESULTS AND DISCUSSION ORIGIN TKW BLITAR}

Blitar is a local part of the province of East Java, with boundaries : (1) north district of Kediri and Malang: (2) east of Malang Regency, (3) ocean south of Indonesia, (4) and west Tulungagung district of Kediri, Blitar region riven with Brantas River, north of Blitar lowland, wetland and wet, while the highlands south of Blitar is critical enough dry land and dry climates.

Total number of job seekers increased every year, but it is also small so that Blitar UMR economic factors driving people Blitar to decide to become migrant workers abroad.

Based on the research results of 2002 on the protection of migrant workers by the UB team, regardless of the negative issues that afflict workers abroad, the workers contribute a great deal to foster socio-economic resilience of their families. Of their remittances from the District 10 Blitar be no longer prone to poverty. Raises awareness of self-employment, appropriate housing, increased health awareness, communication infrastructure and transport and decreased dropout rate.

The woman from Blitar work to meet the needs of their household. Their role not only as a housewife raising and educating their children, but also has been shifted into the backbone of the family. The lack of education and lack of special skills cause women could only work as domestic servants ( PRT ).

Quite often their husbands even allow his wife to work overseas as maids with a reason to meet household needs. The women who work abroad can work 
many years abroad and leave their children. The women usually leave their children with their parents (champion of his children) because these women will have more confidence and not worry if entrust their children to the person who best knows how to take care of and educate children.

The role of the husband in the Java community that should be the backbone of the family, a sudden change, as husband and wife who have their maids become domestic workers or household jobs. Income derived by a woman who worked abroad than her husband is far enough. Are not aware of her husband's role changed and worked on domestic work and just enjoy the fruits of his wife. The husband did not want to work and just waiting for the shipment of his wife .

\section{Culture identity of Javanese women}

The values of Java itself has a lot of concepts about the real woman. The concept of a real woman is always associated with the natural shape of the body and the nature of the woman who then socialized for generations which then forms a difficult even order can not be changed. Nyi Hartati such teachings to his daughter Rancangkapti about " Kias Five Finger Hand ", which tends to weaken kedudukkan women. The teachings reveal that : a) the thumb (the thumb) means Pol Tyas Ing. As a wife should submit to her husband well. What are the husband 's will must be obeyed , b) Accuser (forefinger), means do not ever dare to break tudhung Kakung (hint husband). Instructions husband should not be questioned, c ) Penunggul (middle finger), means always honoring husband and preserve the dignity of man, d) ring finger, meaning keep the water sweet face in serving the husband and if the husband wants something, e) Jejenthik (pinkie) mean wife always athak - ithikan (skilled and resourceful) in any work to serve her husband. In serving the husband should quickly and gently . ( Budi Susanto, et al ; 2000: $24)$.

The concept of real women is manifested in a variety of ancient Javanese literature in the form of classic book, puppet stories, as well as in Modern Javanese literature. As in Panitisastra classic book, only women of reproductive function seen just the ability to bear a child, especially a boy is upheld. 
Items mentioned above teachings are teachings for women of Java, but the patterns of thought contained vast influence that the traditional thinking patterns remain the majority mindset. Though the content rather than the teachings of the grains tend to indulge and serve men. But the public has about the same view on a real woman. This is because people formed the view that the stereotype for women. This view ultimately led to the formulation of the attitudes and behavior of a good woman that appear into the nature of women that seems difficult and can not be changed (AP Murniati in Budi Susanto, et al ; 2000: 25)

\section{CONCEPT Wadon identity, Wanito, Estri, Woman}

Java is the face of women 's oppression. He does not have an equal position with men. Instead, he became a victim of male domination. Here there is a conspiracy of cultural power and strengthen the position of the traditional roles of women.

Women or wanito long time always glued to the properties nrimo, resigne, manas valley, loyal, or smooth. Standardization of this nature tend to be ideological because it appears in the social construction of women who are often marginalized. Inferiority is often a problem for women, because operationalized through social mechanisms, cultural, and power Connection " keapesan " women continue to have tragic fragments . Babad Tanah Jawi explicitly justify any woman unlucky fate .

Though in Java dhosok (acronym), women means women arranged ( layout - titi, Tatas - bead, Tatag - tutug) and wani tapa ( penance -, site -, soles). Indeed under the heel of the woman is the existence of heaven. Convergence between system - tapa, dhikr, immanent transender contemplation and action that is, the predicate kesurgaan very closely with women. For the Javanese, a woman described as a person who should be respected by her because Paradise lies under the feet of mothers ( Purwadi , 2005: 560). At least four people sharing in Java commonly used to refer to women, namely :

Wadon Derived from Kawi, "Wadu " which means servant or servants . In terms can mean that women are commanded in this world as a man of men. 
"Wanito" tebentuk of two words in Java (kerata bases), namely Wani meaning bold and Toto which means regular. Kerata base contains two different senses. First, Wani laid out which means brave ( want ) is set and the. Second, Wani nata which means bold set. Both this sense indicates that women also need a high level in order to properly portray these roles .

Estri Derived from Kawi," Estren" which means panjurung (plunger). Like the famous saying,"There is always a great woman behind a great man."

Daughter In traditional Javanese civilization, this word is often described as an acronym from the words tri perkawis Disconnect, which leads to the full work of women in his capacity as a daughter. Women are required to always realize the woman is three ( tri perkawis ). And is a three- liability position as it is wadon, women, and Estri.

\section{FEMALE DOMESTIC WORKER}

In the life of Javanese women also often we hear the term masak, macak, manak which means a good cook, good at dressing up or preen, and can give offspring. Even though it looks simple terms, but actually three words have deep meaning. (Purwadi , 2005)

Masak Java is not just a woman's job to make / process food, but also nourishes the household that will create a healthy family. In cooking also a woman should have the ability to mix, unite, and combine a variety of materials ate into one so that it becomes a meal. It is a form of affectionate wife to all members of the family .

Macak is up, primp or ornate. Do not be interpreted simply as an activity beautify themselves, because it also contains the meaning of decorate or embellish household buildings. In addition to beautifying the physical, women are also required in order to be able to beautify inner possess a gentle, sincere, compassionate, patient and willing to work hard.

Manak means to bear children or provide offspring. Not just the process of working with the husband in making children, pregnant and gave birth to a baby 
as a descendant. But also includes care of, educate, and establish the characteristics of a child to be fully human.

This can be seen in TKW from Blitar based on data that is as domestic workers into the household cook, baby sister, nurse elderly people, shop assistants and they feel comfortable lives become more valued than their migrant workers in the country on their own. This was stated by Siti TKW from Blitar Lodoyo :

" I worked caring for a newborn, cooking, cleaning the house. Become migrant workers in Hong Kong is not as sordid as people imagine. There, a servant more respected than a maid in Indonesia. In Indonesia, the maid was always considered to be low, trivial, some say even people who do not need to be humanized But in Hong Kong, is completely different. If we go out, for example, to the library, to market, to the hospital. We will be treated the same as the original Hongkong. They remain polite and respect us. My employer also so, they and the brothers always consider me as one family".

Domestic helpers became very interested in since it does not require any special skills and higher education, employment patterns were relatively low with job security.

\section{TKW AND SOCIAL CHANGE}

Javanese women who have in the domestic concept of cooking, Macak, and manak, with maids who work abroad are the majority of domestic and caring family that does not really affect the concept of women instinctively Javanese woman.

The concept of self- maids overseas economic factors that influenced in his household and interpret the important concept of halal and whatever their position is this in ungakapkan worker Siti maids in hongkong Lodoyo Blitar origin ;

"I think it's all work together. During the lawful employmen, why not!!! People who work and earn wages / salaries they are workers. But usually they are more proud to be called a manager, secretary, sales executive or something even bette. Though basically they are working. TKW workers, the President also work, work to serve the people , right?"

The woman from Blitar work to meet the needs of their household. Their role not only as a housewife raising and educating their children, but also has been 
shifted into the backbone of the family. The lack of education and lack of special skills cause women could only work as domestic servants ( PRT ).

Quite often their husbands even allow his wife to work overseas as maids with a reason to meet household needs. The women who work abroad can work many years abroad and leave their children. The women usually leave their children with their parents ( the grandparents ) because these women will have more confidence and not worry if entrust their children to the person who best knows how to take care of and educate children .

The role of the husband in the Java community that should be the backbone of the family, a sudden change, as husband and wife who have their maids become domestic workers or household chores. Income derived by a woman who worked abroad than with her husband very much. Are not aware of her husband 's role changed and worked on domestic work and just enjoy the fruits of his wife. The husband did not want to work and just waiting for the shipment of his wife .

TKW aware of the importance of education, as seen in an interview revealed that in addition to their work they also lecture. On the other hand get paid for capital also in Hong Kong was also studied ;

"The other side maids in Hong Kong other than to obtain capital. We can also get other benefits. Provided that we can take advantage of free time and opportunities. In Hong Kong a lot of formal education (junior open, even if you want to open high school tuition is also available). Non-formal education lebi much more (average free) such as cooking, sewing, bridal makeup , self-employed"

TKW no longer stutter technology, before going abroad HP just does not have, or they can just for phone calls and SMS only, after becoming their maid mastered advanced communication technologies with their facilities . They are familiar with the internet and social media to network more modern ideas and concepts.

Lifestyle in their lives know better discipline and responsibility that they have and feel guilty if they do not do the job on time and carried away when they returned to Indonesia, a foreign language skills other than that they have a part of life. It is based on observations when they return stricken foreigners often use the term in conversation . 
Maids in the concept of beauty in women who have a culture of eastern Indonesia is still in the comparative differences beautify themselves before leaving to become migrant workers and become migrant workers return home after the adoption of the state berdadan way they are headed physically it is very visible, and they can berekplorasi how to dress up and take care of his body to look beautiful.

"Yeah ... a change in me in the form of the body. Which first look fat in Indonesian body weight is now reduced to six heads of four heads. However, the lack of weight is actually considered him sli. Reasons quite well preserved, can buy capsules healthy, eat more regularly and more disciplined."

Women who become migrant workers is not merely a shift, but they still have the concept and understanding of Java women when they return home, as a Javanese woman who has a cooking concept, Macak, and manak but already have a concept of modern thought .

\section{CONCLUSION}

In Javanese women life, we often hear the term masak, macak, manak which means a good cook, good at dressing up or preen, and can give offspring. Even though it looks simple terms, but actually three words have deep meaning. The concept of Javanese women still seems on Indonesian house maids despite a shift.

The existence of TKW from Blitar in the concept of women not only have a concept, masak, macak, and manak but the concept of women who have become migrant workers abroad. Women to work independently, have a higher education and the concept of the use of technology and how to get along with the environment. Raises awareness, appropriate housing, increased health awareness, communication infrastructure and transport and decreased dropout rate. 


\section{Bibliography}

Basrowi dan Sudikin. 2002. Metode Penelitian Kualitatif, Perspektif Mikro. Insan Cendikia. Surabaya.

Cavalli-Sforza, L.L. and W.F. Bodmer. (1971). The Genetics of Human Populations, San Francisco: W.H. Freeman and Co.

DeVito, Joseph A. 1997. Komunikasi Antarmanusia. Proffesional Books. Jakarta.

Fisher, Aubrey, 1986. Teori-Teori Komunikasi perspektif Mekanistis, Psikologis, Interaksional, dan Pragmatis, Penerjemah Soejono Trimo, Remaja Rosdakarya. Bandung.

F. Vogel \& Motulsky, 1979. Human genetics: Problems and approaches. Springer-Verlag. Berlin and New York.

Furchan, Arief. 1992. Pengantar Metode Penelitian Kualitatif. Usaha Nasional. Surabaya.

Garna, Judistira K. 1996. Ilmu-Ilmu Sosial Konsep-Dasar-Posisi. Program Pascasarjana Universitas Padjadjaran. Bandung.

Gudykunst, William B dan Young Yun Kim. 2003. Communicating With Strangers. McGraw Hill. New York.

John W. Berry dkk., 1999. Psikologi Lintas Budaya. Jakarta. Gramedia.

Kartodirdjo, Sartono Prof. Dr. 1992. Pendekatan Ilmu Sosial dalam Metodologi Sejarah. Gramedia Pustaka Utama. Jakarta.

Lewontin, R. C. (1974). The genetic basis of evolutionary change. Columbia University Press. New York.

Lewontin R. C. "Adaptation". Scientific American 239, 212 - 230 (1978).

Moleong, Lexy J. 2007. Metodologi Penelitian Kualitatif. PT. Remaja Rosdakarya. Bandung.

Morisan, Andi, dkk. 2009. Teori Komunikasi. Ghalia Indonesia. Jakarta.

Mulyana, Deddy. 2000. Ilmu Komunikasi Suatu Pengantar. PT. Remaja Rosdakarya. Bandung.

Nazir, Moh. 2003. Metodologi Penelitian. Ghalia Indonesia. Jakarta.

Polomo, Margaret M. 2003. Sosiologi Kontmporer. Terjemahan Tim Penerjemah Yosogama. Rajawali Press. Jakarta. 
Samovar, Larry A dan Richard E. Porter. 1991. Communications Between Cultures. Wodsworth Publishing Company. California.

Zeitlin, Irving M. 1998. Memahami Kembali Sosiologi Kritik Terhadap Teori Sosologi Kontemporer. Universitas Gajah Mada Press. Yogyakarta

Konsep wanita Jawa yang tertuang dalam Novel "Hati Sinden" karya Dwi Rahayuningnsih, 2011 (Yogyakarta : Diva Press).

Kalimat ini mengambil dari buku "Kuasa Wanita Jawa" dan menjadi kalimat iklan dari buku tersebut agar menarik pembacanya. 